\title{
The Expression of Fas Ligand by Macrophages and its Upregulation by Human Immunodeficiency Virus Infection
}

\author{
David H. Dockrell, ${ }^{\star}$ Andrew D. Badley, ${ }^{\star}$ Jorge S. Villacian, ${ }^{\star}$ Carrie J. Heppelmann, ${ }^{\ddagger}$ Alicia Algeciras, ${ }^{\ddagger}$ Steven Ziesmer, ${ }^{\S}$ \\ Hideo Yagita," David H. Lynch, ${ }^{\star \star}$ Patrick C. Roche, $\$$ Paul J. Leibson," and Carlos V. Paya ${ }^{\star \star \|}$ \\ $*$ Division of Infectious Diseases, ${ }^{\star}$ Division of Experimental Pathology, ${ }^{\S}$ Section of Anatomic Pathology, and ${ }^{\|}$Department of \\ Immunology, Mayo Clinic, Rochester, Minnesota 55905; "Juntendo University, School of Medicine, Tokyo 113, Japan; **Immunex \\ Research and Development Corporation, Seattle, Washington 98101
}

\begin{abstract}
Fas/Fas Ligand (FasL) interactions play a significant role in peripheral T lymphocyte homeostasis and in certain pathological states characterized by $T$ cell depletion. In this study, we demonstrate that antigen-presenting cells such as monocyte-derived human macrophages (MDM) but not monocyte-derived dendritic cells express basal levels of FasL. HIV infection of MDM increases FasL protein expression independent of posttranslational mechanisms, thus highlighting the virus-induced transcriptional upregulation of FasL. The in vitro relevance of these observations is confirmed in human lymphoid tissue. FasL protein expression is constitutive and restricted to tissue macrophages and not dendritic cells. Moreover, a significant increase in macrophage-associated FasL is observed in lymphoid tissue from HIV $(+)$ individuals $(P<\mathbf{0 . 0 0 1})$, which is further supported by increased levels of FasL mRNA using in situ hybridization. The degree of FasL protein expression in vivo correlates with the degree of tissue apoptosis $(r=0.761, P<$ 0.001), which is significantly increased in tissue from HIVinfected patients $(P<0.001)$. These results identify human tissue macrophages as a relevant source for FasL expression in vitro and in vivo and highlight the potential role of FasL expression in the immunopathogenesis of HIV infection. $(J$. Clin. Invest. 1998. 101:2394-2405.) Key words: HIV-induced upregulation of FasL in macrophages
\end{abstract}

\section{Introduction}

Fas ligand (FasL) ${ }^{1}$ is a $40-\mathrm{kD}$ type II membrane protein member of the TNF superfamily which induces apoptosis of Fassusceptible target cells (1-5). Apoptosis induced by Fas/FasL interaction plays a key role in the immune system through its

Drs. Dockrell and Badley contributed equally to this paper.

Address correspondence to Carlos V. Paya, Division of Experimental Pathology, Mayo Clinic, 200 First Street SW, Guggenheim 501, Rochester, MN 55905. Phone: 507-284-3747; FAX: 507-284-3757; E-mail: paya@mayo.edu Andrew D. Badley's current address is Division of Infectious Diseases, Ottawa General Hospital, 501 Smythe Ottawa, Ontario, Canada K1H 8M5.

Received for publication 11 July 1997 and accepted in revised form 16 March 1998.

J. Clin. Invest.

(C) The American Society for Clinical Investigation, Inc. 0021-9738/98/06/2394/12 \$2.00

Volume 101, Number 11, June 1998, 2394-2405

http://www.jci.org participation in peripheral $\mathrm{T}$ lymphocyte homeostasis and in lymphocyte-mediated cytotoxicity (6-12). Dysregulation of physiologic Fas/FasL interactions results in immune disease states characterized by enhanced levels of Fas-mediated apoptosis, e.g, AIDS, idiopathic $\mathrm{CD}^{+}{ }^{+} \mathrm{T}$ lymphocytopenia, and a variety of forms of hepatitis or diseases with decreased levels of lymphocyte death (e.g., human autoimmune lymphoproliferative syndrome [ALPS]) (13-18).

The exact mechanism whereby a Fas susceptible peripheral T lymphocyte is depleted by a FasL-expressing immune cell is unknown (19). The presentation of antigen to a T lymphocyte derived from a transformed cell line or hybridomas activated by nonphysiologic stimuli induces susceptibility to Fas-mediated signaling and FasL expression by the lymphocyte within hours resulting in its death by apoptosis $(6-8,20-22)$. However, the induction of susceptibility to Fas-dependent apoptosis in primary $\mathrm{T}$ lymphocytes is thought to require a more prolonged period of time suggesting that the experimental model using transformed cell lines lacks physiologic relevance $(1,6$, 22). An alternative and potentially more physiologic mechanism is that $\mathrm{T}$ lymphocyte activation induces a progressive state of susceptibility to FasL-mediated apoptosis within a few days of the initiation of the immune response. Encounter of the susceptible effector T lymphocyte with a FasL-expressing immune cell would trigger its death by apoptosis. Accumulating evidence indicates that antigen-presenting cells such as macrophages may play a key role in the elimination of activated effector $T$ cells $(14,23-25)$. In view of the potential role of macrophages in $\mathrm{T}$ cell restimulation by recall antigen (2629), FasL expression by macrophages represents a potential mechanism of peripheral $\mathrm{T}$ cell deletion both in physiologic homeostasis but also in disease.

Although the exact mechanism of CD4 T lymphocyte depletion induced by HIV infection remains undefined, previous studies by our group and others indicate that FasL-induced apoptosis represents one possible mechanism, as suggested by the fact that CD4 T lymphocytes from HIV-infected patients have enhanced susceptibility to FasL-mediated apoptosis (13, 14). We have previously demonstrated that HIV infection of monocyte-derived macrophages (MDM) results in upregulation of FasL mRNA which correlates with increased apoptosis of Fas-susceptible targets (30). More recently, MDM-associated FasL was shown to induce a selective apoptosis of Fassusceptible CD4 but not CD8 T cells from HIV-positive patients, implying its potential role in the selective depletion of

1. Abbreviations used in this paper: FasL, Fas ligand; MDDC, monocyte-derived dendritic cell; MDM, MD macrophage; MMP, matrix metalloproteinase; NGS, normal goat serum; TdT, terminal deoxynucleotidyl transferase. 
CD4 T cells (14). Altogether, these in vitro observations support the hypothesis that macrophage-associated FasL may play a role in the deletion of activated peripheral $\mathrm{T}$ lymphocytes in the context of HIV infection.

In this study we have investigated the expression of FasL protein in vitro and in vivo in human macrophages and the mechanisms controlling its upregulation by HIV infection. We demonstrate that monocyte-derived $\mathrm{CD} 14^{+}$macrophages, but not monocyte derived $\mathrm{CD} 83^{+}$dendritic cells, endogenously express FasL, and that HIV infection mediated upregulation of FasL protein expression is independent of posttranslational mechanisms. These in vitro observations correlate with in vivo findings, in which FasL protein is mainly detected within human tissue macrophages in lymphoid tissue. FasL protein and mRNA was found to be upregulated in lymphoid tissue from HIV-infected patients and to correlate with levels of tissue apoptosis. These results suggest that the modulation of FasL expression in macrophages by HIV infection may participate in the homeostasis of peripheral CD4 T cells in HIV infection.

\section{Methods}

Isolation of peripheral blood mononuclear cells and generation of macrophages and dendritic cells cultures. PBMC from healthy blood donors were isolated from buffy coats by density centrifugation using Ficoll Hypaque (Pharmacia LKB Biotechnology Inc., Piscataway, $\mathrm{NJ})$. Cells were cultured at $2 \times 10^{6}$ cells $/ \mathrm{ml}$, in RPMI-1640 media supplemented with $10 \%$ decomplemented human $\mathrm{AB}$ serum (GIBCO BRL, Gaithersburg, MD) plus $2 \mathrm{mmol} /$ liter L-glutamine, $100 \mathrm{U} / \mathrm{ml}$ penicillin $\mathrm{G}$ and $100 \mu \mathrm{g} / \mathrm{ml}$ streptomycin (Whittaker Bioproducts, Walkersville, MD), in a $5 \% \mathrm{CO}_{2}$ atmosphere at $37^{\circ} \mathrm{C}$. PBMC underwent plastic adherence in horizontally placed T175 tissue flasks (Corning-Costar, Cambridge, MA). To generate enriched populations of MDM or monocyte-derived dendritic cells (MDDC) the following procedures were performed. After $24 \mathrm{~h}$, the nonadherent cells (PBL) were removed and the adherent monocytes were detached by washing in PBS, further separated from contaminating lymphocytes by density centrifugation in a $14.5 \%$ metrizamide gradient (Sigma Chemical Co., St. Louis, MO) and $8 \times 10^{6}$ cells plated at $2 \times 10^{6}$ cells/ $\mathrm{ml}$ in 6-well plates (Corning-Costar). To enrich for MDM 24-h plastic adhered monocytes were cultured with GM-CSF, $800 \mathrm{U} / \mathrm{ml}$ (Immunex Corp., Seattle, WA) and TNF, $100 \mathrm{U} / \mathrm{ml}$ (Genzyme, Cambridge, MA) (31). To enrich for MDDC 24-h plastic-adhered monocytes were cultured with GM-CSF, $800 \mathrm{U} / \mathrm{ml}$ and IL-4, $500 \mathrm{U} / \mathrm{ml}$ (R \& D Systems, Inc., Minneapolis, MN) and from the fifth day of culture TNF, $100 \mathrm{U} / \mathrm{ml}$ was added (31). Adherent cells were passed every $3 \mathrm{~d}$ in RPMI-1640 with $10 \%$ low FBS containing undetectable levels of LPS (Hyclone Laboratories Inc., Logan, UT). In experiments determining the role of HIV infection on FasL expression by MDM, the 24-h nonadherent cells were removed and the adherent monocytes were cultured with $10 \%$ FBS media without added cytokines. Adherent cells in flasks were passed every $7 \mathrm{~d}$. In experiments evaluating the effect of metalloproteinase inhibition, KB8301 (gift from Kanebo, Ltd., Osaka, Japan) at $20 \mu \mathrm{M} / \mathrm{ml}$ was added for $24 \mathrm{~h}$ before harvest.

Viral stock and HIV infection. HIV stocks of the M-tropic strain SF162 were prepared from the supernatants of PHA and IL-2treated PBMC as previously described (30). Cell-free culture supernatants containing HIV or mock-infected supernatant were filtered, aliquoted, and stored at $-120^{\circ} \mathrm{C}$. The $\mathrm{TCID}_{50}$ of the HIV stock was determined as previously described (32). 5-d-old MDM in T175 flasks were infected with a TCID ${ }_{50}$ of $5 \times 10^{4}$ of HIV p24 containing supernatant per flask for $24 \mathrm{~h}$ at $37^{\circ} \mathrm{C}$ in $5 \% \mathrm{CO}_{2}$. In parallel, mock-infection was performed using the mock-infected supernatant under the same conditions. MDM monolayers were then washed three times and cultured in RPMI-1640 with low LPS $10 \%$ FBS with refeeding every $7 \mathrm{~d}$. MDM were harvested by incubation in ice-cold PBS and gently scraped. HIV infection in MDM was monitored by screening p24 content using a commercial ELISA (Coulter, Hialeah, FL). In certain experiments intracytoplasmic p24 was analyzed by flow cytometry using anti-p24 FITC (Coulter).

ELISA for soluble FasL detection. Culture conditions for the detection of soluble FasL in the supernatants from MDM were as follows: HIV- or mock-infected MDM were scraped $7 \mathrm{~d}$ after infection and reseeded at $3 \times 10^{6} / \mathrm{ml}$ in 24 well plates (Corning-Costar). Cellfree supernatants were harvested on day 12 after infection. The concentration of soluble FasL was normalized to the number of MDM counted in each well at the end of the incubation period. Culture supernatants were stored at $-120^{\circ} \mathrm{C}$ until analyzed. Soluble FasL was detected by ELISA as previously described using antibodies kindly provided by H. Yagita (Juntendo University, Tokyo, Japan) (33). Briefly $50 \mu \mathrm{l}$ of anti-FasL mouse IgM (NOK-3) at $10 \mu \mathrm{g} / \mathrm{ml}$ was crosslinked in PBS overnight at $4^{\circ} \mathrm{C}$ to Immulon $4^{\circledR}$ plates (Dynatech Labs. Inc., Chantilly, VA). Antibody containing wells were blocked with $1 \%$ milk-PBS for $2 \mathrm{~h}$ at $37^{\circ} \mathrm{C}$ after which $50 \mu \mathrm{l}$ of culture supernatant was added to duplicate wells and incubated for $1 \mathrm{~h}$ at room temperature (RT). As reference serial dilutions of recombinant soluble FasL were used. $50 \mu \mathrm{l}$ of biotinylated anti-FasL IgG1 (NOK-1) at $5 \mu \mathrm{g} / \mathrm{ml}$ was then added for $1 \mathrm{~h}$ at RT, followed by $50 \mu \mathrm{l}$ of ABC solution (Vector Laboratories, Burlingame, CA) for $1 \mathrm{~h}$ at RT, with wash steps with PBS $0.05 \%$ Tween performed in between each step. The reaction was developed using $100 \mu \mathrm{l}$ of OPD (Sigma Chemical Co.) for $1 \mathrm{~h}$ at RT and stopped using $100 \mu \mathrm{l}$ of $2 \mathrm{~N} \mathrm{H}_{2} \mathrm{SO}_{4}$. The optical density was measured at $490 \mathrm{~nm}$ and values estimated by comparing the optical density obtained to the standard curve.

Flow cytometry. Flow cytometry for surface staining was performed on $10^{6} \mathrm{MDM}$ or MDDC. $100 \mu \mathrm{g}$ of human IgG1 (Sigma Chemical Co.) was added to all cell pellets for $15 \mathrm{~min}$ at $4^{\circ} \mathrm{C}$, washed three times with PBS followed by a 15 -min incubation at $4^{\circ} \mathrm{C}$ with the appropriate antibody. $1 \mu \mathrm{g}$ of the following antibodies were used: CD14 FITC mouse IgG2b, CD83 mouse IgG2a, p24 FITC mouse $\mathrm{IgG} 1, \mathrm{IgG} 2 \mathrm{~b}$ mouse FITC isotype, IgG1 mouse FITC isotype (Coulter), IgG2a mouse isotype (Sigma Chemical Co.), FasL (NOK-1) phycoerythrin conjugate (PE) mouse IgG1 (33) and IgG1 mouse PE isotype (Caltag Laboratories, South San Francisco, CA). Where appropriate, cells were then washed and incubated with goat antimouse FITC (Becton Dickinson, San Jose, CA) at $10 \mu \mathrm{g}$ for $15 \mathrm{~min}$ at $4^{\circ} \mathrm{C}$. For certain experiments intracytoplasmic staining was performed by fixing $10^{6} \mathrm{MDM}$ in $1 \%$ paraformaldehyde containing 20 $\mu \mathrm{g} / \mathrm{ml}$ of lysolecithin (Sigma Chemical Co.) for $5 \mathrm{~min}$ at $4^{\circ} \mathrm{C}$. Samples were next washed, permeabilized in $2 \mathrm{ml}$ of ice-cold methanol while vortexing, placed on ice for $15 \mathrm{~min}$, washed, and resuspended in $1 \mathrm{ml}$ of PBS $0.1 \%$ NP-40 (Sigma Chemical Co.) for $5 \mathrm{~min}$ at $4^{\circ} \mathrm{C}$; $100 \mu \mathrm{g}$ of human IgG1 added for $15 \mathrm{~min}$ at $4^{\circ} \mathrm{C}$, cells washed and incubated with $1 \mu \mathrm{g}$ of the appropriate antibody for $15 \mathrm{~min}$ at $4^{\circ} \mathrm{C}$. Flow cytometry was performed using a FACScan ${ }^{\circledR}$ (Becton Dickinson) and analysis completed using CELL QUEST ${ }^{\circledR}$ software (Becton Dickinson). All samples were compared to their isotype-matched controls. In the case of dual flow cytometry individual samples treated with each isotype alone were used to determine the background levels of autofluorescence.

In situ hybridization. A 322-bp DNA fragment corresponding to bases 373-694 of the human FasL genome (34) was obtained by PCR from cDNA using the following primers; anti-sense: T CCG CTC GAG CTC ATC ATC TTC CCC T, sense: CCG GAA TTC ATC TTT GGA GAA GC and cloned into a Bluescript SK vector (Stratagene, La Jolla, CA) with EcoR1 and XhoI flanking sites in the antisense and sense directions, respectively. To generate an antisense RNA probe the plasmid was linearized with EcoR1 and transcribed using T7 polymerase (Promega Corp., Madison, WI). For the FasL sense probe, XhoI was used to linearize the template and transcription was performed using T3 RNA polymerase (Promega Corp., Madison, WI). In vitro transcription reaction and digoxigenin 11UTP (Boehringer-Mannheim, Indianapolis, IN) labeling were per- 
formed after commercial kits (Promega Corp.). Labeled probes were digested with deoxyribonuclease (Promega Corp.) phenol/chloroform extracted, and ethanol precipitated. In situ hybridization was performed on formalin fixed paraffin-embedded tissues after xylene and graded alcohol treatment as previously described (35). Hybridization with riboprobe at $1 / 80$ dilution was performed overnight at $37^{\circ} \mathrm{C}$. Positive in situ hybridization signals were detected by the antidigoxigenin AP at 1/200 dilution (Boehringer-Mannheim) using the NBT/BCIP system.

Immunofluorescence staining of paraffin-embedded tissue. Tissues were obtained from HIV-positive patients undergoing biopsy to rule out malignancy whose nodes were found to be free of malignancy or other pathologic abnormality as judged by independent pathological review. These HIV-infected patients had CD4 T cell counts less than 300 cells $/ \mathrm{mm}^{3}$, and had not received combination antiretroviral therapy. Tissues from HIV-negative patients used as controls were obtained at the time of biopsy to exclude malignancy and the tissues utilized contained no pathological abnormalities. An additional number of tissues from HIV-negative patients with pathologic abnormalities (B cell lymphomas; small lymphocytic type, follicular small cleaved cell type or diffuse large cell type or Kikuchis necrotizing lymphadenitis) were also analyzed in certain experiments to determine the specificity of HIV-related FasL expression. 5- $\mu \mathrm{m}$ sections of paraffinembedded tissue were treated with xylene to remove paraffin and rehydrated through graded alcohol to water washes and endogenous peroxidase activity was quenched by a 10-min incubation in a 50:50 mix of methanol: $3 \%$ peroxidase. Antigen retrieval was performed by treatment with steaming $10 \mathrm{mM}$ citrate buffer for $30 \mathrm{~min} \mathrm{pH} 6.0$ and subsequent cooling. Sections were then washed in water, rinsed in PBS $0.05 \%$ Tween, incubated with $100 \mu \mathrm{g} / \mathrm{ml}$ human IgG1 (Sigma Chemical Co.) for $15 \mathrm{~min}$, and then with $5 \%$ normal goat serum (NGS), (ICN Pharmaceuticals Inc., Costa Mesa, CA) in PBS for 15 min. To stain for CD68, tissue slides were incubated with $300 \mu \mathrm{l}$ of PGM-1 antibody (anti-CD68) antibody (36) (Dako, Carpinteria, CA), at a 1:100 dilution in 1\% NGS PBS for $60 \mathrm{~min}$ at room temperature, followed by biotin conjugated, goat anti-mouse (Dako) 1:100 dilution in 1\% NGS PBS for $30 \mathrm{~min}$ and streptavidin FITC (Dako) 1:200 dilution for $30 \mathrm{~min}$ with wash steps in between each incubation as above. To stain for S100, a 1:300 dilution of S100 antibody (37) (Dako) in 1\% NGS PBS was used and slides incubated for $60 \mathrm{~min}$ at RT, followed by incubation with biotin conjugated goat anti-mouse (Dako) and streptavidin FITC (Dako) as above. Anti-CD68 or anti-
S100 processed slides were then incubated with $2.5 \mu \mathrm{g} / \mathrm{ml}$ of NOK-1 PE (33) in 1\% NGS PBS overnight at room temperature. Coverslips were placed with vectashield (Vector Laboratories) to retain fluorescence, and slides were viewed and photographed with filters which allow only red light wavelength fluorescence (excitation $546 \mathrm{~nm}$, emission $590 \mathrm{~nm}$ ) or green light wavelength fluorescence (excitation 450-490 nm, emission 515-565 nm). In some experiments involving staining of FasL, slides were treated with NOK-1 (33) or IgG1 isotype at $2.5 \mu \mathrm{g} / \mathrm{ml}$ overnight and catalysed signal amplification (CSA) (Dako) performed with the amplification reagent at $40 \%$ and conditions as per the manufacturers instructions. Amino-ethyl-carbazole (Sigma Chemical Co.) was used as chromogen and slides counterstained with hematoxylin. To determine specificity of the NOK-1 antibody preabsorption of NOK-1 $(2.5 \mu \mathrm{g} / \mathrm{ml})$ with soluble FasL $(5 \mu \mathrm{g} /$ $\mathrm{ml}$ ) was performed at $4^{\circ} \mathrm{C}$ for $12 \mathrm{~h}$ and the mixture was thereafter used in the immunostaining process as described above. This resulted in the elimination of FasL-specific staining, thus supporting the specificity of this antibody for the immunostaining of FasL in tissues, as previously described (38). In those experiments involving dual FasL and apoptosis staining, slides were first incubated overnight with FasL PE, washed in PBS-Tween followed by apoptosis detection using Apotag direct ${ }^{\circledR}$ (Oncor, Gaithersberg, MD) with terminal deoxynucleotidyl transferase (TdT) and FITC-conjugated nucleotide triphosphate. Thereafter, slides were reviewed by three blinded reviewers who reviewed 10 randomly chosen fields to quantify the number of FasL-positive cells and apoptotic cells in each $40 \times$ objective field.

Statistical analysis. Statistical analysis was performed using a Signed Rank test and pairwise comparisons were made using a paired $t$ test. Comparison of fold increase in soluble FasL after HIV treatment was performed using a one tailed $t$ test for comparison of means with significance defined as $P<0.05$. To determine the relationship of FasL to apoptosis, a Spearman correlation coefficent was calculated using SAS system software.

\section{Results}

FasL is expressed by monocyte-derived macrophages but not by monocyte-derived dendritic cells. Our group has previously demonstrated that FasL mRNA transcription is constitutively present in monocyte derived macrophage cultures (30). In
Donor \#1
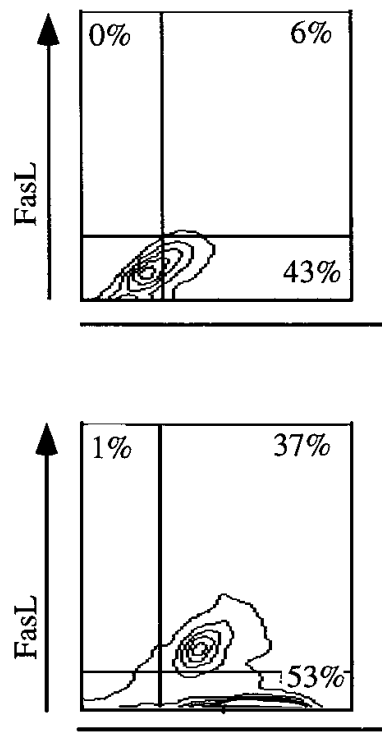

Donor \#2

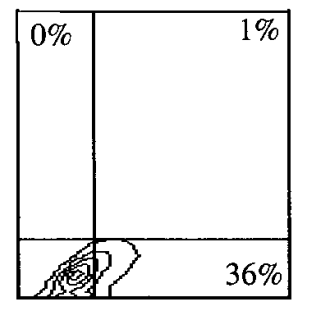

\section{83}

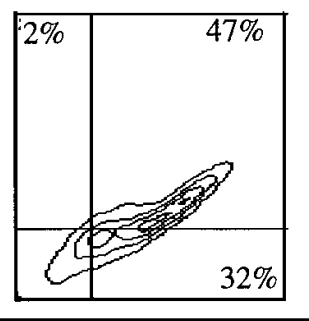

CD14
Donor \#3
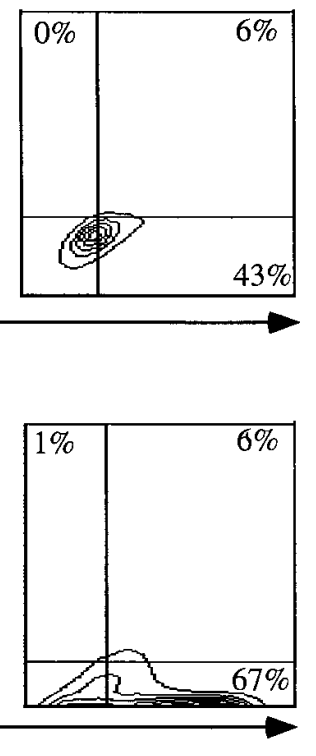

Figure 1. FasL expression in MDM and MDDC. Membrane associated FasL in MDDC and MDM was determined for 12-d-old cell cultures derived from three separate blood donors. Dual flow cytometry was performed using anti-FasL antibody(NOK-1) PE and either anti-CD83 and a goat antimouse FITC antibody- or antiCD14 FITC antibody. For each cell type isotype $\mathrm{PE}$ and isotype FITC antibodies were used to determine quadrant position and specific fluorescence. For each donor the percentage of cells with dual positivity for FasL and either CD83 or CD14 is indicated in the right upper quadrant. 
vitro cultures of freshly isolated peripheral blood monocytes are capable of differentiating into both macrophages and dendritic cells and thus contain a nonhomogeneous cellular population of monocytes at different stages of differentiation (39, 40). To better define the monocyte derived subpopulation(s) that express endogenous FasL, plastic-adhered monocytes were treated with different cytokine mixtures which allow for the enrichment of two defined populations, $\mathrm{CD} 14^{+}$cells (here defined as MDM) and monocyte-derived dendritic $\mathrm{CD}^{+} 3^{+}$ cells (MDDC) $(31,40)$. Treatment of monocytes for $12 \mathrm{~d}$ with TNF and GM-CSF resulted in cultures containing a mean of 87\% (range 73-95\%) of CD14 expressing adherent cells. In parallel, a mixture of IL4, TNF, and GM-CSF yielded loosely adherent nests of cells with typical dendritic veils containing a mean of $61 \%$ (range 37-83\%) of cells expressing the specific dendritic cell marker CD83. Using this culture technique, we next proceeded to measure membrane-associated FasL expression in MDM and in MDDC generated from three separate donors. As shown in Fig. 1, MDDC $\left(\mathrm{CD} 83^{+}\right)$had no detectable FasL on their surface, which is in direct contrast with the detectable FasL expression by MDM $\left(\mathrm{CD} 14^{+}\right)$cells; the degree of which is donor dependent. These results indicate that in vitro culture of peripheral blood monocytes leads to FasL expression in $\mathrm{CD}_{14}^{+}$macrophages, but not in MDDC, and highlights the endogenous expression of FasL protein by a primary immune cell.

FasL expression by MDM is increased by HIV infection. Previous studies from our group indicate that HIV-infected MDM cultures upregulate FasL mRNA and selectively induce the apoptosis of FasL susceptible primary CD4 T cells from HIV (+) individuals $(14,30)$. Whether HIV infection, in addition to upregulating FasL transcription, also influences the posttranslational regulation of FasL expression remains unknown. HIV infection of macrophages induces the upregulation of certain matrix metalloproteinases (MMP) (41), some of which may be responsible for the posttranslational processing of membrane bound FasL to its soluble form $(33,42)$. Therefore, we questioned whether HIV infection might also modify the posttranslational processing of FasL by MMP-like converting enzymes in addition to its effects on FasL transcription. Mock- or HIV-infected MDM were pretreated for $24 \mathrm{~h}$ with the MMP inhibitor (KB8301) after which membrane-associated and soluble FasL were measured by flow cytometry and ELISA, respectively. In MDM, the MMP inhibitor resulted in a proportional increase in the level of membrane-associated FasL in both mock- and HIV-infected MDM (Fig. $2 A$ ). To confirm that the effects of this MMP inhibitor targeted the processing of the membrane-bound into the soluble form of FasL, parallel culture supernatants were collected from cells treated with or without KB8301. As shown in Fig. $2 \mathrm{~B}$, a decrease in soluble FasL is observed in mock-infected MDM or HIV-infected MDM cultures treated with KB8301. The apparent lack of direct correlation between the degree in the increase in membrane-bound FasL and the decrease in soluble FasL induced by KB8301 may reflect a more rapid degradation of the soluble form in the culture supernatant, a larger soluble pool, or limitation of the ELISA sensitivity.

The observed upregulation of FasL in HIV-infected MDM cultures could be the direct result of HIV infection of individual cells, or alternatively it could be the indirect result of cytokines and/or soluble viral proteins produced by HIV-infected cells. To address this question, dual flow cytometry was per-
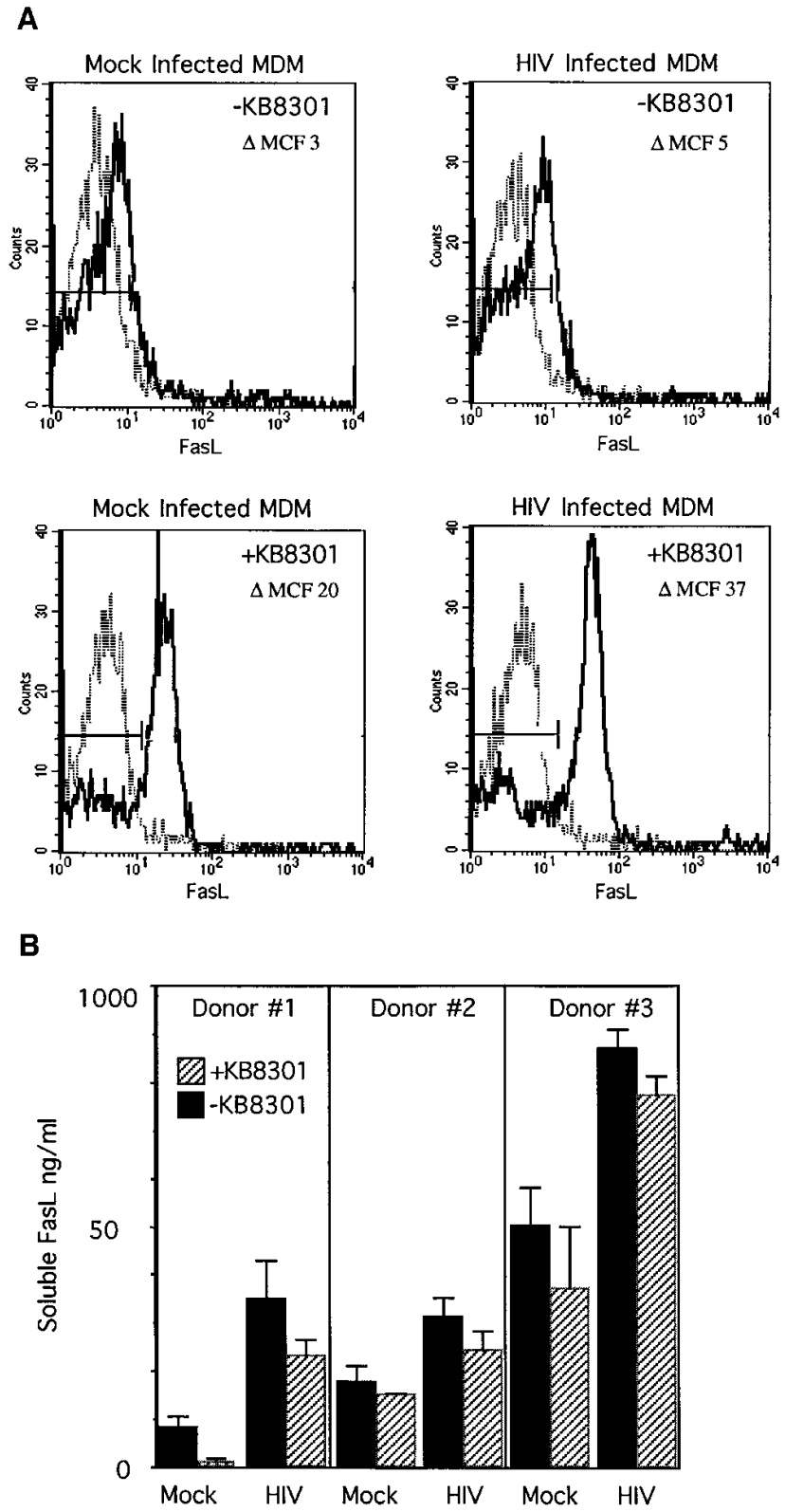

Figure 2. HIV infection upregulates FasL expression. (A) Flow cytometry of mock-infected or HIV-infected MDM in the absence $(-)$ or presence $(+)$ of $24 \mathrm{~h}$ treatment with $20 \mu \mathrm{M} \mathrm{KB} 8301$. Cells were harvested and stained with isotype antibody (broken line) or antiFasL antibody (NOK-1) PE (bold line). Mean channel fluorescence was determined by subtracting the isotype value from the FasL stained specimen value. $(B)$ Soluble FasL levels in duplicate culture supernatants from mock- or HIV-infected MDM treated with or without KB8301 as in $(A)$ obtained from three separate donors. Data is representative of 12 donors studied.

formed on permeabilized mock- or HIV-infected MDM from various donors to detect intracytoplasmic p24 and FasL. As shown in Fig. 3, a direct correlation between the degree of FasL and HIV-p24 was observed in one donor; phenomena which was further confirmed in two additional donor MDM. The direct relationship between p24 and FasL expression was found to be statistically significant $(P<0.01)$. However, the 

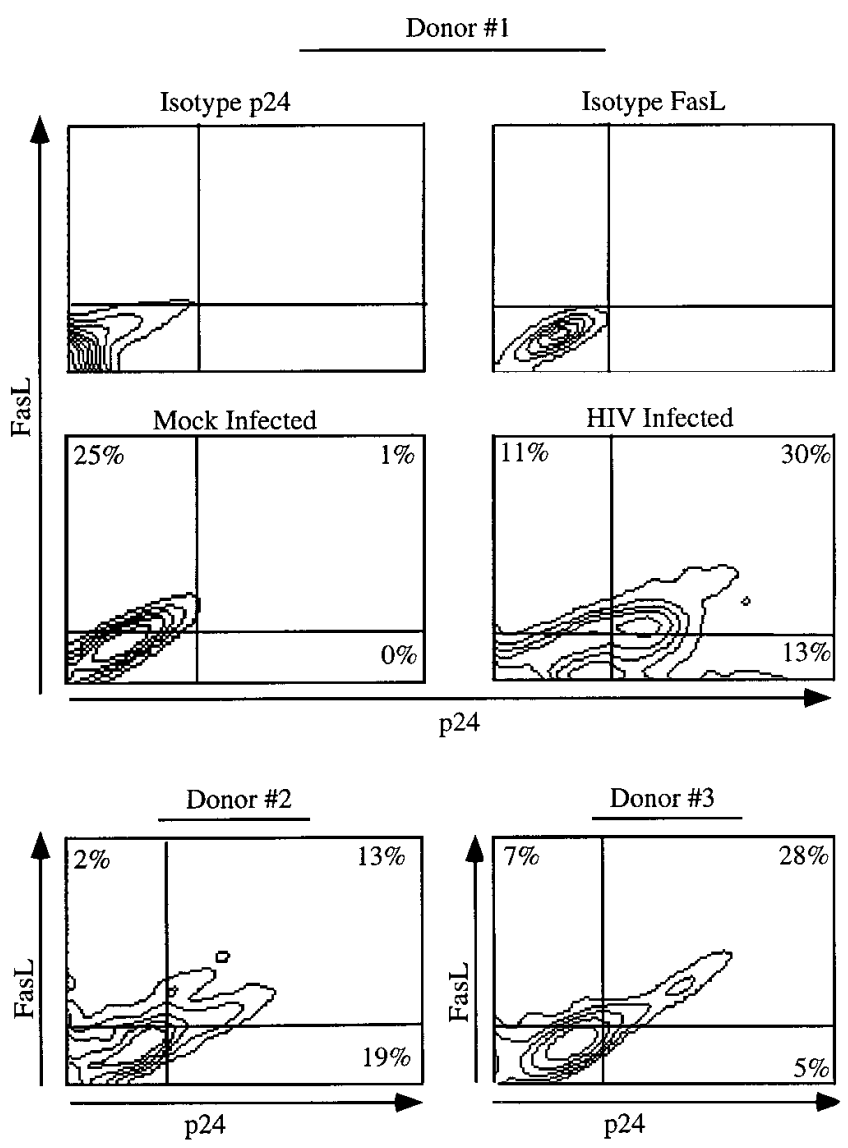

Figure 3. FasL and HIV expression in MDM. Dual flow cytometry of intracytoplasmic p24 and FasL in 12 d after mock- or HIV-infected MDM. Individual PE isotype or FITC isotype stained specimens were used for each specimen to determine the position of specific fluorescence (donor \#1). Dual staining in two additional donors (donors \#2 and \#3). The percentage of dual positive cells is depicted in the upper right quadrant for each donor.

fact that $\mathrm{p} 24(+) \mathrm{MDM}$ within the HIV-MDM cultures contain significant levels of FasL negative cells also argues for a role for indirect mechanisms related to HIV infection.

FasL is expressed by macrophages in human lymphoid tissue and is increased in HIV-infected individuals. The above experiments demonstrate that in addition to the inducible form of FasL that can be detected in vitro in $\mathrm{T}$ lymphocytes, a basal expression of this protein is present in in vitro-cultured MDM. As the immune relevance of the two separate forms of FasL in these two different types of immune cells remains unknown, we reasoned that investigating the expression of FasL in vivo in lymphoid tissue and identifying its cellular association could provide additional information about its potential role in $\mathrm{T}$ cell homeostasis. Paraffin-embedded sections from a variety of lymphoid tissues (lymph node, tonsil, small intestine, and colon) obtained from HIV-negative individuals and considered not to have abnormal pathology were first screened. Anti-FasL antibodies (NOK1-PE) were used in conjunction with antibodies that recognize different immune cell subsets. We first evaluated whether FasL expression (if detectable) was restricted to tissue macrophages. For this, we utilized an antiCD68 antibody, routinely used in immunohistopathology to stain for tissue macrophages (PGM1) (36). Results from these experiments are summarized in Fig. $4 A$, which demonstrate that FasL expression is constitutively present in lymphoid tissue. FasL is localized in the lymphoid tissue of the small and large bowel within the subepithelial region. In lymph nodes, FasL expression is observed in the interfollicular and paracortical regions; considered to be rich in macrophages and $\mathrm{T}$ cells. Most striking was the fact that the FasL $(+)$ cells were found to be CD68(+); although a large proportion of CD68(+) cells were FasL $(-)$, suggesting that it is a subpopulation of tissue macrophages within normal lymphoid tissue that express FasL. As dendritic cells of monocytic origin may also contain CD68 (43), we performed additional studies in which FasL staining was correlated with S100; a marker for dendritic cells (37). Following the same approach as for CD68 staining, tissues were costained for FasL and S100. Results from representative experiments demonstrate that $\operatorname{FasL}(+)$ cells were found to be $\mathrm{S} 100(-)$ (Fig. $4 \mathrm{~B}$ ), indicating that FasL expression is restricted to the CD68(+)/S100(-) population, which is thought to correspond to differentiated tissue macrophages. Moreover, these studies did not detect significant levels of constitutive FasL in T lymphocytes which are CD68(-).

Due to the potential relevance of constitutive FasL expression by tissue macrophages to the depletion of Fas susceptible CD4 T cells, as previously documented by our group using in vitro studies (14), we evaluated whether the in vivo expression of this apoptosis-inducing ligand is upregulated in a disease state characterized by increased CD4 T cell depletion, i.e., HIV infection. To achieve this, we compared in parallel, lymph nodes from a series of three $\operatorname{HIV}(+)$ patients with those obtained from three random $\mathrm{HIV}(-)$ patients. Using the same experimental design as described above, we first determined whether FasL expression was comparable between HIV(-) and $\mathrm{HIV}(+)$ tissue using the anti-FasL antibody (NOK1-PE). A significant increase in $\operatorname{FasL}(+)$ cells was found in tissue from $\mathrm{HIV}(+)$ patients (Fig. $5 A$ ), which as in lymph node tissue from $\mathrm{HIV}(-)$ patients, was restricted to $\mathrm{CD} 68(+)$ and S100( - ) cells (Fig, 5, $A$ and $B$ ). This suggested that either an overall increase in the number of $\mathrm{CD}^{+} 8^{+}$cells, of which a subset is FasL $(+)$, is present in the lymphoid tissue from $\mathrm{HIV}(+)$ patients, or alternatively, that a larger proportion of CD68(+) cells are FasL $(+)$ in tissue from $\operatorname{HIV}(+)$ patients. To address this, the number of CD68 $(+)$ and FasL $(+)$ cells were individually quantified in the lymph nodes from $\mathrm{HIV}(-)$ and $(+)$ patients. A summary of this evaluation tabulated in Table I indicates that while the number of CD68(+) cells was found to be similar between HIV $(-)$ and $(+)$ tissues, highly significant increases in the number of FasL $(+)$ cells were present in the lymph nodes from $\mathrm{HIV}(+)$ patients. We also examined FasL expression in lymph nodes from patients with a variety of $\mathrm{B}$ cell lymphomas and in cases of Kikuchis lymphadenitis, a disease associated with tissue apoptosis and thought to be of viral etiology (44). These studies demonstrated that FasL expression in these two pathological conditions was not increased as compared to control lymph node tissue (not shown). Altogether, this first set of experiments confirm the in vivo expression of FasL protein in macrophages and highlight its significant upregulation in lymphoid tissue from HIV-infected individuals.

To further confirm the HIV-dependent FasL upregulation in vivo, and to address potential mechanisms regulating its expression, an in situ hybridization technique for the detection of 


\section{Lymph node}
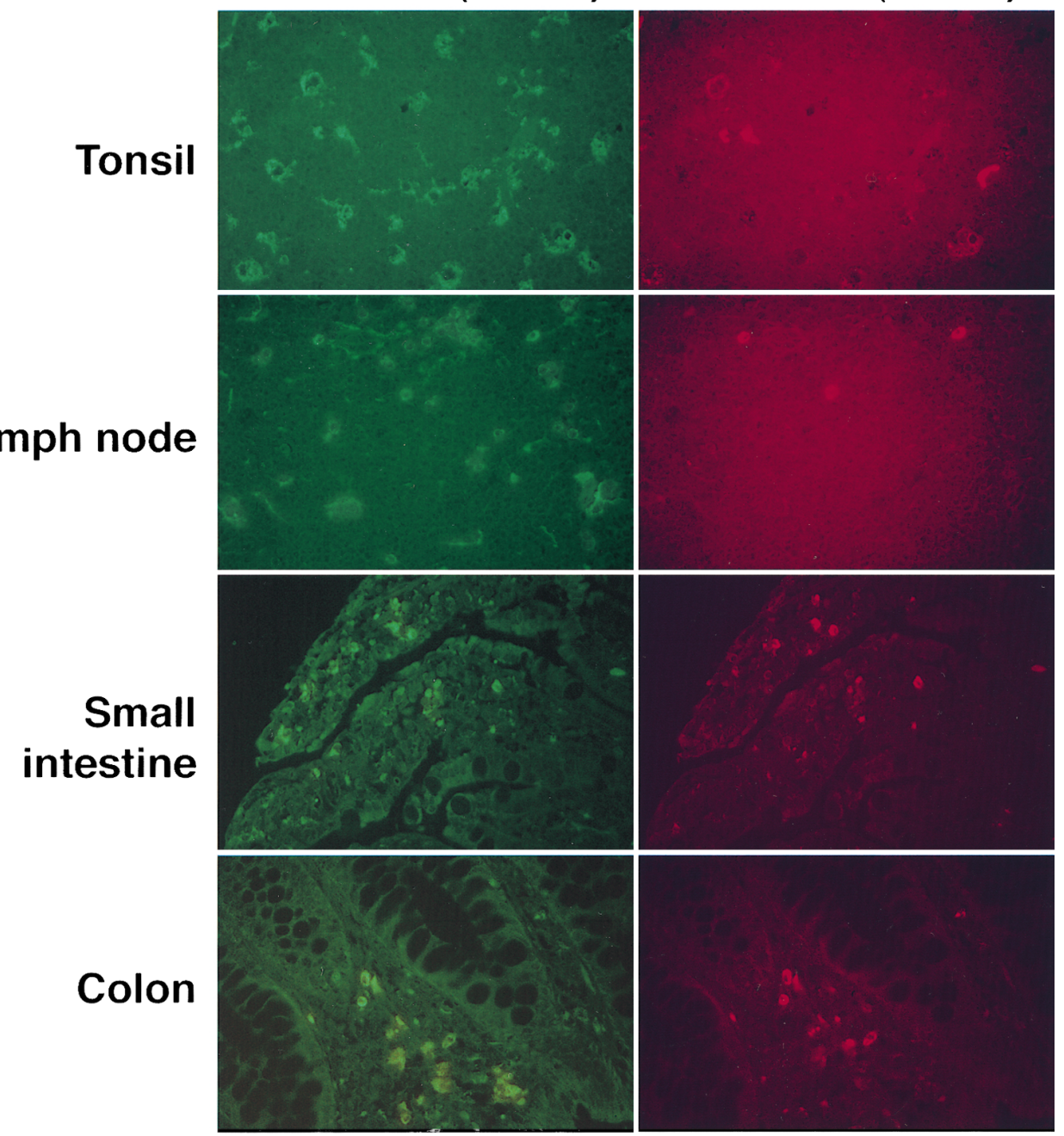

B

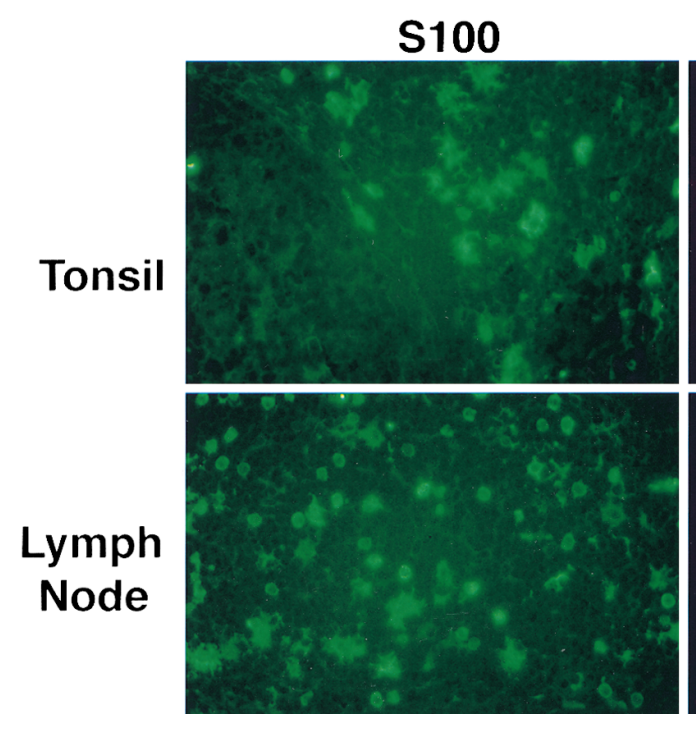

anti FasL (NOK1)

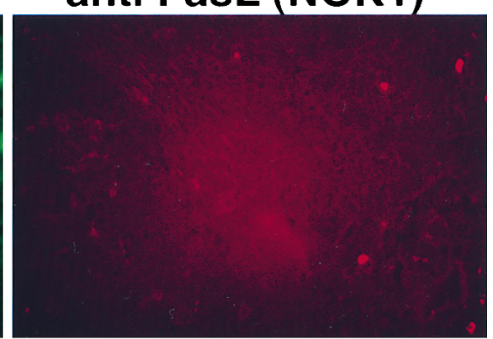

Figure 4. FasL expression in vivo. (A) Paraffin-embedded tissue from a variety of lymphoid tissues obtained from $\operatorname{HIV}(-)$ individuals was stained with antiCD68 (PGM-1) and anti-FasL $(\mathrm{NOK}-1)$ antibodies. $\mathrm{CD} 68^{+}$ cells stain green while FasL + cells stain red. $(B)$ Sections were stained with anti S100 (S100); green, and anti-FasL antibodies $(N O K-1)$; red.

FasL mRNA was developed. Using this technique, we demonstrate the presence of FasL mRNA in lymphoid tissue from both control and HIV-infected individuals. Moreover, a significant increase in the number of cells expressing FasL mRNA were observed in the lymphoid tissue from HIV-infected pa- tients with the morphologic appearance of lymphocytes in addition to tissue macrophages (Fig. 6).

FasL expression correlates with increased tissue apoptosis. To determine whether the FasL protein expression in lymphoid tissue correlates with increased levels of tissue apoptosis 

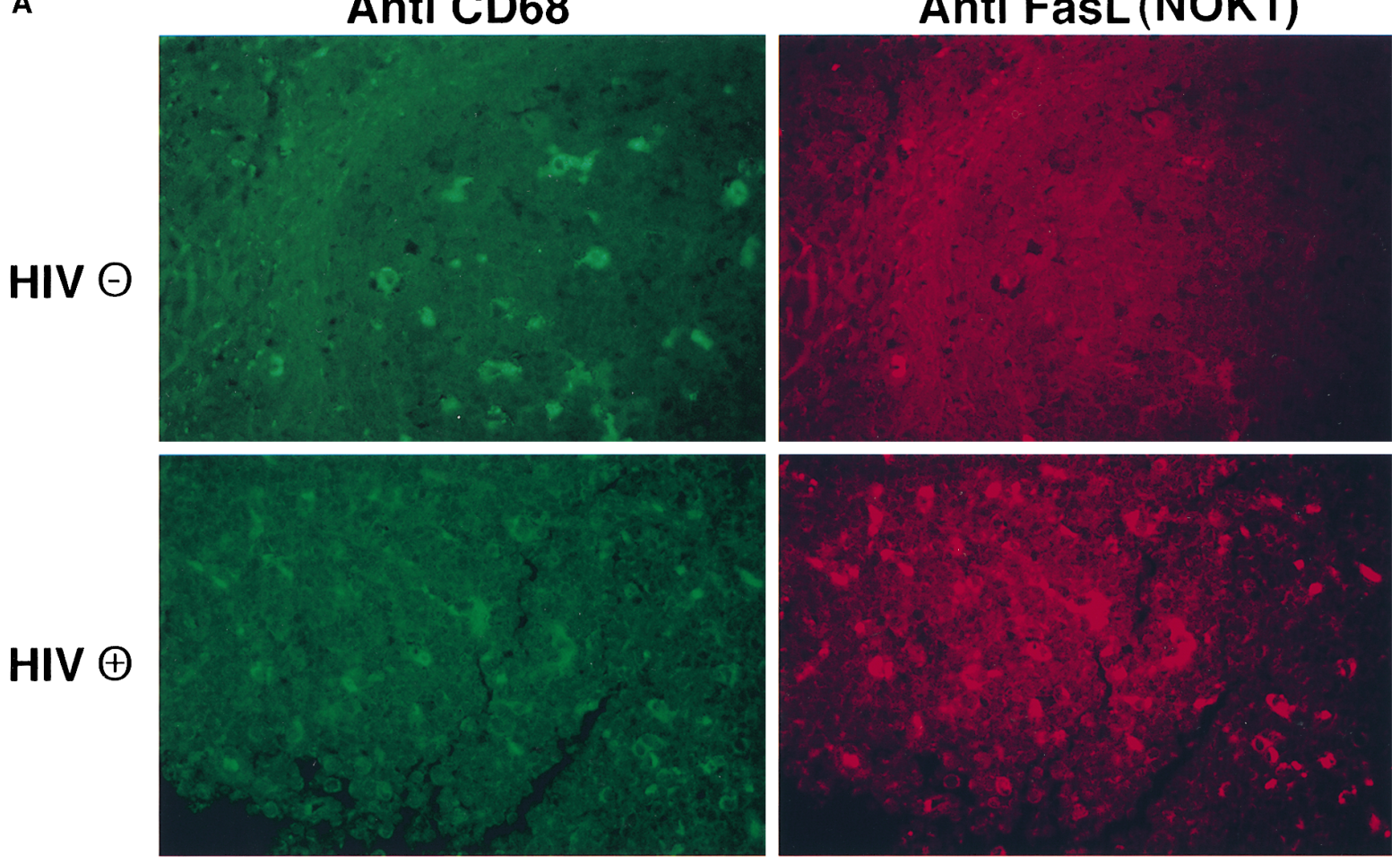

B

S100

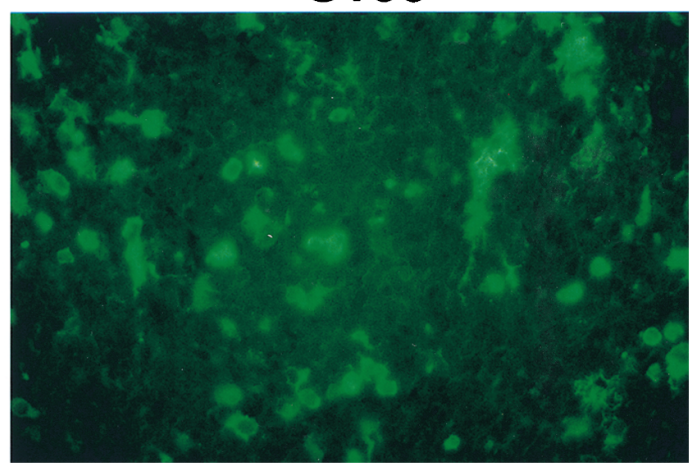

HIV $\Theta$

HIV $\oplus$

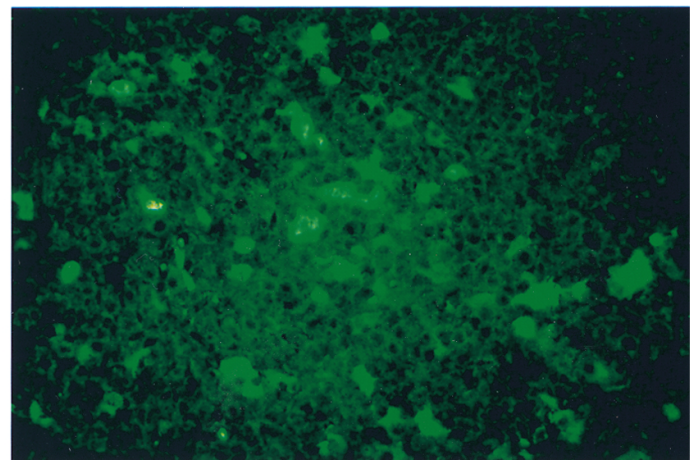

\section{Anti FasL (NOK1)}
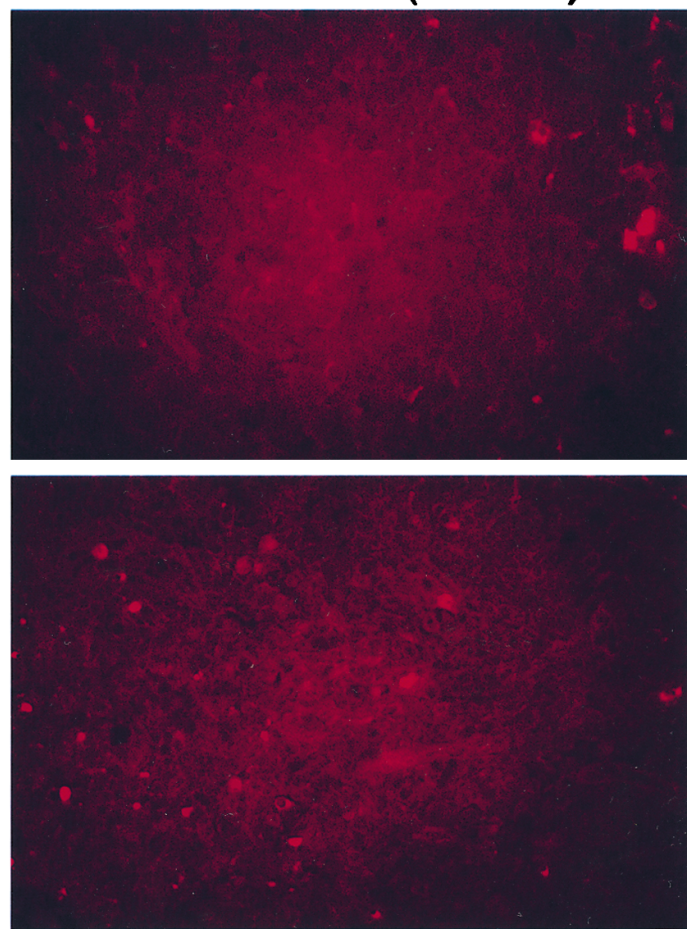

Figure 5. Comparison of FasL expression in lymph node tissue from $\mathrm{HIV}(-)$ and $\mathrm{HIV}(+)$ patients. $(A)$ Paraffin-embedded tissues from HIV $(-)$ or HIV $(+)$ patients stained with anti-CD68 and anti-FasL antibodies as described in Fig. 4. (B) Paraffin-embedded tissue from HIV $(-)$ and HIV $(+)$ patients stained with anti S100 or anti-FasL antibodies as described in Fig. 4. 
Table I. FasL Expression in CD68 Cells in Lymph Nodes from HIV(-) and HIV(+) Patients

\begin{tabular}{|c|c|c|c|c|c|c|c|c|c|c|c|c|}
\hline & \multicolumn{3}{|c|}{ Lymph node \#1 } & \multicolumn{3}{|c|}{ Lymph node \#2 } & \multicolumn{3}{|c|}{ Lymph node \#3 } & \multicolumn{3}{|c|}{ Total } \\
\hline & NI & HIV & $P$ & NI & HIV & $P$ & NI & HIV & $P$ & NI & HIV & $P$ \\
\hline PGM1 & 19.4 & 20.5 & 0.42 & 20.7 & 21.5 & 0.78 & 18.2 & 23.0 & 0.001 & 19.4 & 21.5 & 0.01 \\
\hline NOK1 & 3.0 & 17.7 & $<0.001$ & 2.3 & 18.2 & $<0.001$ & 2.8 & 18.9 & $<0.001$ & 2.7 & 18.1 & $<0.001$ \\
\hline Percent NOK1 & $16 \%$ & $86 \%$ & $<0.001$ & $12 \%$ & $86 \%$ & $<0.001$ & $16 \%$ & $81 \%$ & $<0.001$ & $14 \%$ & $84 \%$ & $<0.001$ \\
\hline
\end{tabular}

we stained tissue specimens for FasL and quantified apoptosis using terminal deoxynucleotide UTP transferase (TUNEL). Three HIV(-) and three HIV(+) lymphoid tissues were analyzed and as depicted in representative fields of $\mathrm{HIV}(-)$ and $\operatorname{HIV}(+)$ tissue (Fig. $7 A$ ), the level of both FasL and the number of apoptotic cells was greater in the HIV $(+)$ tissues. Three independent reviewers blinded as to the source of tissue reviewed 10 randomly chosen fields at a magnification of 40 for each tissue. In HIV (-) tissues the mean number of FasL positive cells per $40 \times$ objective was 5.2, standard deviation 1.0 , and the mean number of apoptotic cells was 7.1, standard deviation 3.1 compared with a mean number of FasL positive cells per field of 18.4, standard deviation 5.3 ( $P<0.001$ paired $t$ test) and a mean number of apoptotic cells per field of 23.3, standard deviation $7.2(P<0.001$ paired $t$ test $)$ in the HIV $(+)$ tissues. To determine if a significant correlation existed between the numbers of FasL-positive cells and the number of apoptotic cells, a linear regression analysis was performed using data from both HIV $(-)$ and HIV $(+)$ tissues (Fig. 7 B). This analysis demonstrated a significant correlation between the frequency of apoptosis and the number of FasL-expressing cells; which as shown above are $\mathrm{CD}^{+} 8^{+}(r=0.761$, Spearman correlation) $(P=<0.001)$. In a few cases the apoptotic cells were in physical contact with FasL positive cells. In all HIV $(+)$ tissues there were higher numbers of apoptotic cells correlating with increased numbers of FasL expressing cells. Multiple efforts were made to identify the phenotype of the TUNEL $(+)$ cells in the frozen tissue slides by immunostaining. While anti-CD68 antibodies combined with the TUNEL technique indicated that the TUNEL $(+)$ were not $\mathrm{CD}^{+} 8^{+}$, antibodies against CD3 or CD4 did not stain any cells, thus limiting our ability to determine whether the TUNEL $(+)$ cells were of T lymphocyte phenotype.

\section{Discussion}

This study provides novel evidence demonstrating that differentiated macrophages are a constitutive source of FasL in the immune system. The functional relevance of apoptosis-inducing ligands such as FasL and, as previously identified, TNF in

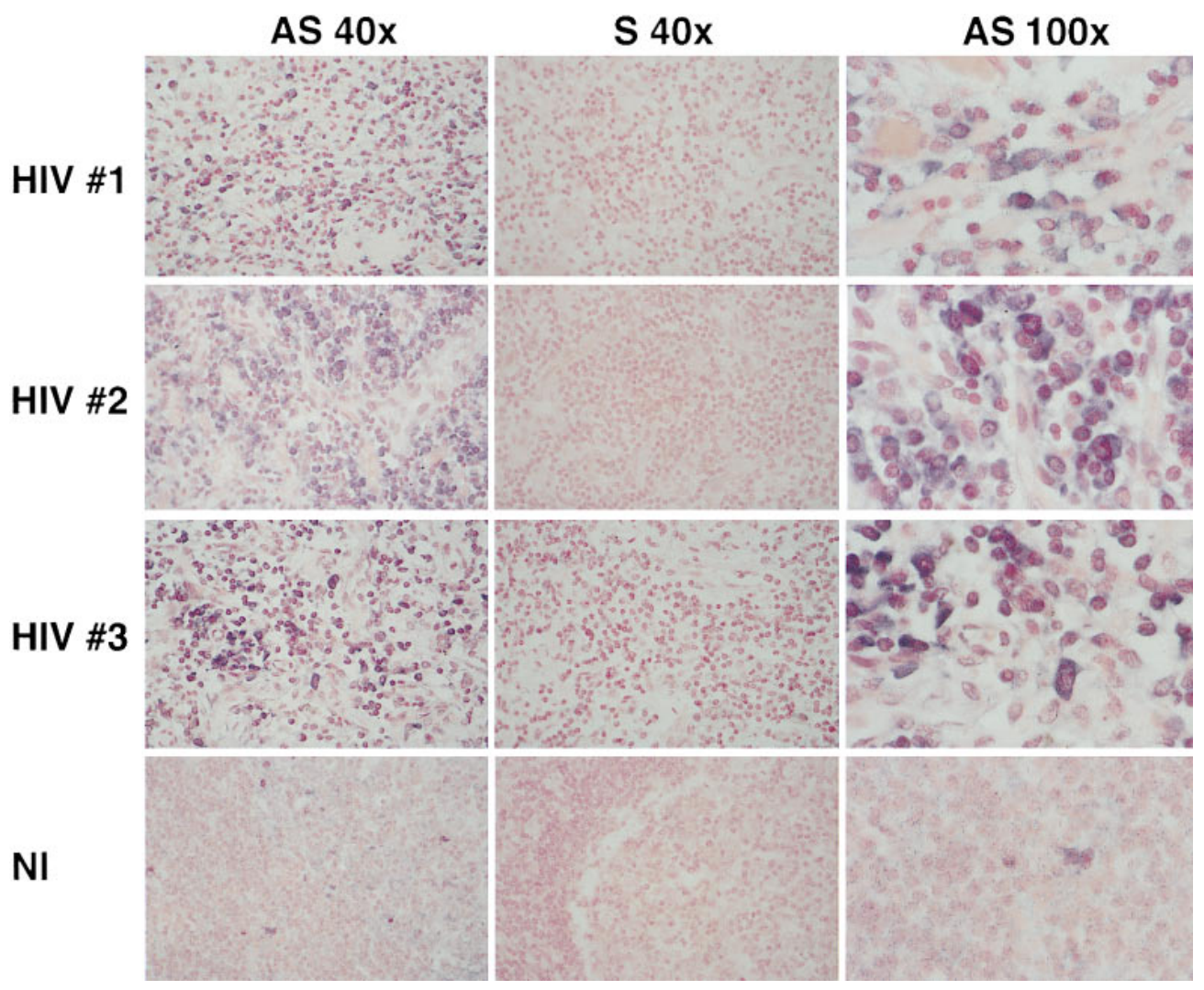

Figure 6. Comparison of FasL mRNA expression in lymph tissue from $\operatorname{HIV}(-)$ and $\operatorname{HIV}(+)$ patients as detected by in situ hybridization. Paraffin-embedded tissues from $\mathrm{HIV}(-)$ or $\mathrm{HIV}(+)$ tissue were treated with FasL anti-sense $(A S)$ or FasL sense $(S)$ riboprobes to detect mRNA for FasL. The first three rows represent data from three HIV $(+)$ tissues, the fourth row from a control HIV $(-)$ patient $(N I)$. The first and third columns show results with the FasL anti-sense probe at magnifications of 40 and 100 . The middle column shows the result obtained with the FasL sense riboprobe at a magnification of 40 . 
Apoptosis
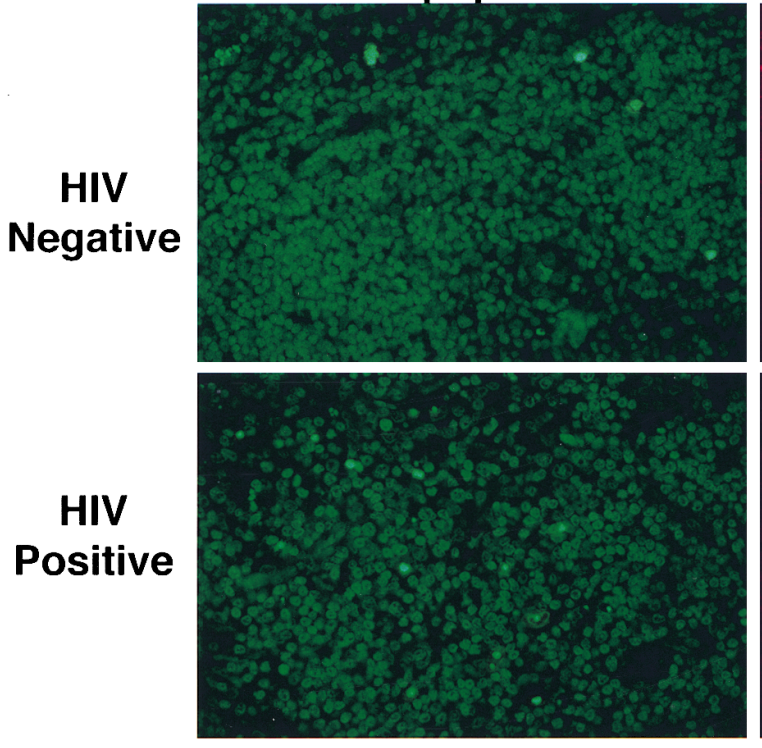

B

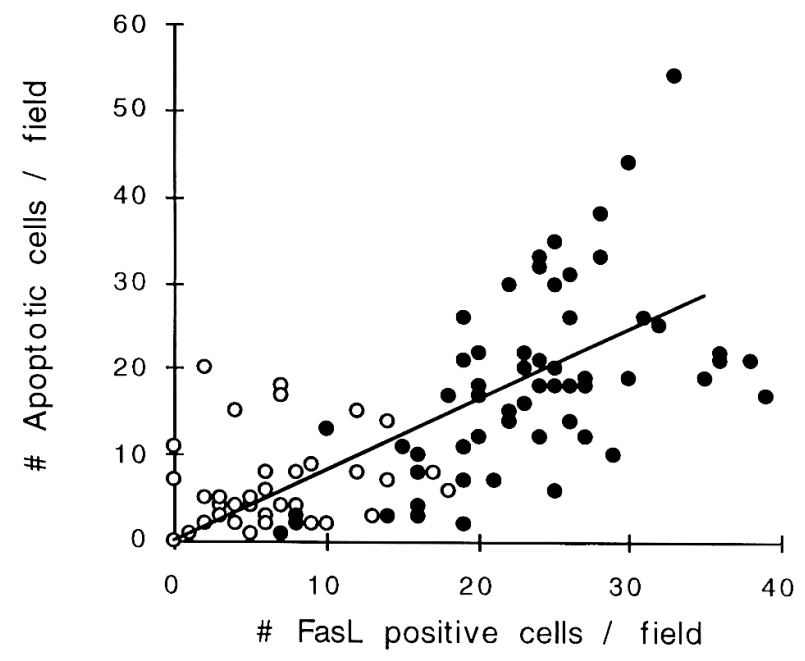

FasL
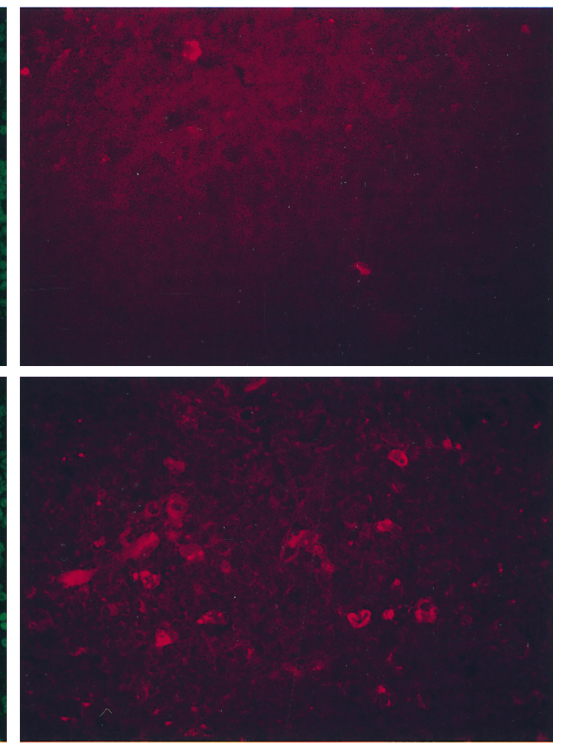

- HIV
- Control

$R=0.718$

$\mathrm{P}=<0.001$
Figure 7. Tissue FasL and tissue apoptosis are augmented in lymph nodes from HIV positive patients. Paraffin sections of lymph nodes from $\mathrm{HIV}(-)$ and $\operatorname{HIV}(+)$ tissues were stained simultaneously with anti-FasL (NOK-1 PE) and by TUNEL assay to detect apoptosis. $(A)$ Representative sections of lymph nodes from three HIV(-) tissues (upper panels) and three $\mathrm{HIV}(+)$ tissues (lower panels) show apoptosis detected by TUNEL assay (green, left panels), and FasL detected by NOK-1 PE (red, right panels).

Left and right panels are the same sections viewed under different filters. $(B)$ Results from the analysis of all three $\mathrm{HIV}(-)$ and all three $\mathrm{HIV}(+)$ tissues as reviewed by three blinded reviewers and plotted and analyzed by linear regression. Open circles represent data from $\mathrm{HIV}(-)$ tissues and closed circles data from $\mathrm{HIV}(+)$ tissues. Spearman correlation coefficent $r=0.761, P<0.001$. human macrophages (45) is unclear. The key role that both FasL and TNF play in the homeostasis of peripheral $\mathrm{T}$ lymphocytes (46), raises the counterintuitive possibility that macrophages may participate in the depletion of activated, apoptosis-susceptible $\mathrm{T}$ cells. Recent in vitro studies support this concept, as activated macrophages have been shown to induce the selective apoptosis of susceptible CD4 T cells (23), and our group has demonstrated that HIV-infected macrophages induce the selective apoptosis of CD4 T cells through Fas/FasL interactions $(14,30)$. This putative new role of macrophages therefore questions the relevance of lymphocyte-associated FasL as the exclusive source of this apoptosis-inducing ligand in the immune system and highlights the potential role of the macrophages in regulating peripheral $\mathrm{T}$ cell homeostasis and in the pathogenesis of disease states characterized by enhanced lymphocyte depletion such as the AIDS.

As demonstrated in this study, FasL expression could not be detected in vivo in monocyte-derived dendritic $\left(\mathrm{CD} 83^{+}\right)$ cells, or in vivo in $\mathrm{S} 100^{+}$cells. These observations can be reconciled by the finding that the murine dendritic cells express- ing FasL are of lymphocytic, but not monocytic origin, and that the FasL-negative dendritic cell subpopulation induces the most potent cell proliferation in MLR (47-49). The immunological impact of MDM-associated FasL in vivo is unknown and warrants further study. While MDM can serve as antigenpresenting cells, this function is regarded as suboptimal when compared to that exerted by dendritic cells with regard to novel antigen presentation to naive $\mathrm{T}$ cells. On the contrary, MDM appear to be the main antigen-presenting cell of recall antigen to memory T cells (26-29); thus potentially leading to their apoptosis and deletion.

While studies are underway to test the impact of macrophage-associated FasL in the physiology of peripheral $\mathrm{T}$ cell homeostasis, this study has focused on the potential role of macrophage-associated FasL in disease states such as HIV infection in which enhanced $\mathrm{T}$ cell apoptosis and depletion occur. Previous in vitro studies from our group demonstrated that infection of MDM with monocytotropic strains of HIV upregulates FasL mRNA and their ability to trigger apoptosis of susceptible CD4 T cells $(14,30)$. Using this in vitro model 
we first addressed whether HIV modulates FasL through transcriptional independent mechanisms, as FasL undergoes posttranslational upregulation by matrix metalloproteinases (33, 42); enzymes shown to be upregulated by HIV infection (41). Results from our studies indicated that there was no detectable HIV-specific upregulation of the processing of the membranebound FasL into soluble form. This suggests that the increase in membrane-bound FasL in HIV-infected MDM is secondary to transcriptional upregulation of the gene, as previously shown by our group (30). This is relevant to the potential deletion of CD4 T cells by MDM, as previous studies have demonstrated that membrane-bound, rather than soluble FasL, is more effective in inducing apoptosis of Fas-susceptible Jurkat $\mathrm{T}$ cells (50). Moreover, we have previously demonstrated that induction of Fas-dependent apoptosis of susceptible $\mathrm{CD}^{+} \mathrm{T}$ cells by HIV-infected MDM requires cell-to-cell contact (14), even though soluble FasL is significantly increased in the supernatant of HIV-MDM cells. Future studies should aim at identifying how HIV infection results in the transcriptional regulation of the FasL gene.

A second group of in vitro experiments addressed whether the in vitro HIV-dependent upregulation of FasL was mediated by direct HIV infection, or indirectly by HIV-dependent mechanisms. Using double immunostaining techniques, we have concluded that both mechanisms must be involved. Both p24 ${ }^{+}$and p24- MDM present within HIV-infected MDM cultures express increased levels of FasL proteins, suggesting that soluble products present in HIV-infected cultures, in addition to direct HIV infection of the cell may play a role in increasing FasL expression. In this regard, CD4 activation by gp120 has been recently shown to increase FasL protein expression in monocytes (51) and to increase FasL gene transcription through the upregulation of the FasL gene enhancer-promoter region (52). Whether other HIV-soluble proteins and/or cytokines/chemokines that are produced by MDM after HIV infection also upregulate FasL transcription and protein expression needs to be addressed (53).

Having advanced our understanding of the cell-specific expression of FasL by macrophages and the regulation of its expression by HIV infection in in vitro models, we next wanted to translate these observations and their potential relevance to in vivo circumstances. Using specific immunostaining techniques, it was possible to demonstrate that within nondiseased lymphoid organs and tissues from control individuals a constitutive level of FasL was present in tissue macrophages (CD68 ${ }^{+}$) but not in dendritic cells (S100); closely paralleling the in vitro findings. Whereas, only a minority of $\mathrm{CD} 68^{+}$cells expressed FasL in control tissue, the majority of $\mathrm{CD}^{+} 8^{+}$cells present in lymphoid organs from HIV-infected patients expressed FasL. Technical limitations have limited our ability to perform double in vitro PCR of HIV RNA and immunostaining for FasL; however, the fact that $>80 \%$ of $\mathrm{CD}^{+} 8^{+}$cells express FasL suggests that expression of this protein is not directly related to HIV infection of the host cell, especially when $<1 \%$ of tissue macrophages have been identified to contain HIV and tissue macrophages are estimated to be the source of $<1 \%$ of the lymphoid tissue pool of $\operatorname{HIV}(54,55)$. It is therefore plausible that indirect mechanisms triggered by HIV infection rather than solely direct HIV infection are responsible for FasL upregulation, as suggested and discussed for the in vitro studies addressing this question.

Due to the striking similarities observed so far between the in vitro and in vivo studies we next pursued whether the presumed HIV-dependent gene transcription of the FasL gene could be detected in vivo using hybridization techniques. FasL mRNA was observed in a number of cells in lymphoid tissue from control HIV-negative individuals, confirming the basal level of FasL protein expression in lymphoid organs. More relevant to the focus of this study was the observation that a significant large number of cells per field of lymphoid tissue from HIV-positive individuals expressed FasL mRNA, suggesting that the upregulation of FasL in vivo is likely responsible for the increased FasL protein expression in lymphoid tissue from HIV-positive individuals. Of interest, the morphological phenotype of FasL mRNA containing cells was not only restricted to macrophages, but also to cells of lymphocyte morphology. The apparent discrepancy between enhanced FasL mRNA level in these different immune cells and the restriction of FasL protein expression to tissue macrophages could be explained by at least two mechanisms. One is the limitation in the sensitivity of the immunostaining technique as compared to the in situ hybridization. It is plausible that cells other than tissue macrophages also express FasL protein, especially in lymphoid tissue from HIV-positive patients, but the sensitivity of FasL immunostaining enables only the detection of FasL protein in those cells with higher levels of expression, such as tissue macrophages. Alternatively, FasL transcription may be enhanced not only in macrophages but in other immune cells, but cell-specific differences with regard to the translational regulation of FasL protein could result in different levels of membrane protein expression.

The relevance of the enhanced FasL expression in lymphoid tissue from HIV-positive patients was addressed using apoptosis as a functional endpoint. The correlation between the number of FasL-expressing cells and the number of apoptotic cells within the same field points to the participation of Fas/FasL interactions in the high degree of lymphoid tissue apoptosis that was observed in HIV-positive patients. The role of apoptosis in causing the T cell depletion that results in HIVpositive patients has remained highly controversial; even though a defined molecular mechanism(s) responsible for this $\mathrm{T}$ cell depletion remains to be established. While our study's main aim was to investigate the correlation between the expression of FasL in macrophages and its regulation by HIV infection both in vitro and in vivo, additional preliminary data demonstrated a parallel between the degree of tissue apoptosis and FasL, which need to be followed by a more detailed analysis of the nature of the cells within lymphoid tissue that are undergoing apoptosis. Preliminary results indicate that the apoptotic cells are not $\mathrm{CD} 68^{+}$, suggesting that cells other than tissue macrophages such as lymphocytes may be the ones undergoing apoptosis. However, further attempts to identify the apoptotic cells phenotype were unsuccessful and studies are ongoing to address this issue. In fact, other investigators have concluded that cells extracted from lymphoid tissue from $\mathrm{HIV}(+)$ individuals, rather than directly staining fixed tissue as used in our study, have a high degree of apoptosis which can be observed in both CD4 and CD8 T cells (56). It is therefore possible that the findings from our study may provide a useful model in which it can be determined whether Fas/FasL interactions play or not play a role in T cell depletion in HIV-infected patients. If the increase in FasL protein levels in lymphoid tissue from these patients is in direct correlation with increased T cell apoptosis, both of which may be virus dependent, future studies 
should evaluate whether decreasing viral load using highly active antiretroviral therapy significantly modifies Fas/FasL interactions in vivo and their correlation with lymphoid tissue apoptosis and peripheral T lymphocyte levels.

\section{Acknowledgments}

The authors would like to thank Drs. Paul Kurtin and John Strickler for histopathological advice, Drs. Ricardo Lloyd and Long Jin for their most valuable technical assistance with in situ hybridization, Teresa Hoff for secretarial assistance, and members of the Paya Laboratory for helpful discussion.

Dr. Badley is supported by a grant from Physicians Services Incorporated Foundation and the AIDS Program Committee of Ontario.

\section{References}

1. Suda, T., T. Takahashi, P. Golstein, and S. Nagata. 1993. Molecular cloning and expression of the Fas ligand, a novel member of the Tumor Necrosis Factor family. Cell. 75:1169-1178.

2. Trauth, B.C., C. Klas, A.M.J. Peters, S. Matzku, P. Moller, W. Falk, K.-M. Debatin, and P.H. Krammer. 1989. Monoclonal antibody-mediated tumor regression by induction of apoptosis. Science. 245:301-305.

3. Suda, T., and S. Nagata. 1994. Purification and characterization of the Fas-ligand that induces apoptosis. J. Exp. Med. 179:873-879.

4. Tanaka, M., T. Suda, T. Takahashi, and S. Nagata. 1995. Expression of the functional soluble form of human Fas ligand in activated lymphocytes. EMBO J. 14:1129-1135.

5. Suda. T., T. Okazaki, Y. Naito, T. Yokota, N. Arai, S. Ozaki, K. Nakao, and S. Nagata. 1995. Expression of the Fas ligand in cells of T cell lineage. J. Immunol. 154:3806-3813.

6. Dhein, J., H. Walczak, C. Baumler, K.-M. Debatin, and P.H. Krammer. 1995. Autocrine T-cell suicide-mediated by APO-1/(Fas/CD95). Nature. 373: 438-441.

7. Brunner, T., R.J. Mogil, D. LaFace, N.J. Yoo, A. Mahboubi, F. Echeverri, S.J. Martin, W.R. Force, D.H. Lynch, C.F. Ware, and D.R. Green. 1995. Cell-autonomous Fas (CD95)/Fas-ligand interaction mediates activation-induced apoptosis in T-cell hybridomas. Nature. 373:441-444.

8. Ju, S.-T., D.J. Panka, H. Cui, R. Ettinger, M. El-Khatib, D.H. Sherr, B.Z. Stanger, and A. Marshak-Rothstein. 1995. Fas (CD95)/FasL interactions required for programmed cell death after T-cell activation. Nature. 373:444-448.

9. Singer, G.G., and A.K. Abbas. 1994. The Fas antigen is involved in peripheral but not thymic deletion of $\mathrm{T}$ lymphocytes in $\mathrm{T}$ cell receptor transgenic mice. Immunity. 1:365-371.

10. Russell, J.H., B. Rush, C. Weaver, and R. Wang. 1993. Mature T-cells of autoimmune $\mathrm{lpr} / \mathrm{lpr}$ mice have a defect in antigen stimulated suicide. Proc. Natl. Acad. Sci. USA. 90:4409-4413.

11. Arase, H., N. Arase, and T. Saito. 1995. Fas-mediated cytotoxicity by freshly isolated natural killer cells. J. Exp. Med. 181:1235-1238.

12. Kagi, D., F. Vignaux, B. Ledermann, K. Burki, V. Depraetere, S. Nagata, H. Hengartner, and P. Golstein. 1994. Fas and perforin pathways as major mechanisms of T cell-mediated cytotoxicity. Science. 265:528-530.

13. Katsikis, P.D., E.S. Wunderlich, C.A. Smith, L.A. Herzenberg, and L.A. Herzenberg. 1995. Fas antigen stimulation induces marked apoptosis of T lymphocytes in human immunodeficiency virus-infected individuals. J. Exp. Med. 181:2029-2036.

14. Badley, A.D., D. Dockrell, M. Simpson, R. Schut, D.H. Lynch, P. Leibson, and C.V. Paya. 1997. Macrophage-dependent apoptosis of CD4 ${ }^{+}$T lymphocytes from HIV-infected individuals is mediated by FasL and tumor necrosis factor. J. Exp. Med. 185:55-64.

15. Laurence, J., D. Mitra, M. Steiner, D. Lynch, F.P. Siegal, and L. StaianoCoico. 1996. Apoptotic depletion of $\mathrm{CD}^{+}{ }^{+} \mathrm{T}$ cells in idiopathic CD4 ${ }^{+} \mathrm{T}$ lymphocytopenia. J. Clin. Invest. 97:672-680.

16. Galle, P.R.,. W.J. Hofmann, H. Walczak, H. Schaller, G. Otto, W. Stremmel, P.H. Krammer, and L. Runkel. 1995. Involvement of the CD95 (Apo-1/Fas) receptor and ligand in liver damage. J. Exp. Med. 182:1223-1230.

17. Muller, M., S. Strand, H. Hug, E-M. Heinemann, H. Walczak, W.J. Hofmann, W. Stremmel, P.H. Krammer, and P.R. Galle. 1997. Drug induced apoptosis in hepatoma cells is mediated by the CD95 (APO-1/Fas) receptor/ligand system and involves activation of wild-type p53. J. Clin. Invest. 99:403-413.

18. Fisher, G.H., F.J. Rosenberg, S.E. Straus, J.K. Dale, L.A. Middelton, A.Y. Lin, W. Strober, M.J. Lenardo, and J.M. Puck. 1995. Dominant interfering Fas gene mutations impair apoptosis in a human autoimmune lymphoproliferative syndrome. Cell. 81:935-946.

19. Strasser, A. 1995. Death of a T cell. Nature. 373:385-386.

20. Vignaux, F., E. Vivier, B. Malissen, V. Depraetere, S. Nagata, and P. Golstein. 1995. TCR/CD3 coupling to Fas-based cytotoxicity. J. Exp. Med. 181:
$781-786$.

21. Nagata, S., and T. Suda. 1995. Fas and Fas ligand: 1 pr and gld mutations. Immunol. Today. 16:39-43.

22. Boehme, S.A., and M.J. Lenardo. 1993. Propriocidal apoptosis of mature $\mathrm{T}$ lymphocytes occurs at $\mathrm{S}$ phase of the cell cycle. Eur. J. Immunol. 23: 1552-1560.

23. Munn, D.H., J. Pressey, A. Beall, R. Hudes, and M.R. Alderson. 1996. Selective activation-induced apoptosis of peripheral $\mathrm{T}$ cells imposed by macrophages. J. Immunol. 156:523-532.

24. Wu, M.X., J.F. Daley, R.A. Rasmussen, and S.F. Schlossman. 1995. Monocytes are required to prime peripheral blood $\mathrm{T}$ cells to undergo apoptosis. Proc. Natl. Acad. Sci. USA. 92:1525-1529.

25. Cottrez, F., F. Manca, A.G. Dalgleish, F. Arenzana-Seisdedos, A. Capron, and H. Groux. 1997. Priming of human $\mathrm{CD}^{+}$antigen-specific T cells to undergo apoptosis by HIV-infected monocytes; a two step process involving the gp120 molecule. J. Clin. Invest. 99:257-266.

26. Macatonia, E., S. Patterson, and S.C. Knight. 1991. Primary proliferation and cytotoxic T-cell responses to HIV induced in vitro by human dendritic cells. Immunology. 74:399-406.

27. Mehta-Damani, A., S. Markowicz, and E.G. Engleman. 1994. Generation of antigen-specific CD8 ${ }^{+}$CTLs from naive precursors. J. Immunol. 153: 996-1003.

28. Mehta-Damani, A., S. Markowicz, and E.G. Engleman. 1995. Generation of antigen-specific $\mathrm{CD}^{+}{ }^{+} \mathrm{T}$ cell lines from naive precursors. Eur. J. Immunol. 25:1206-1211.

29. Takamizawa, M., A. Rivas, F. Fagnoni, C. Benike, J. Kosek, H. Hyakawa, and E.G. Engleman. 1997. Dendritic cells that process and present nominal antigens to naive $\mathrm{T}$ lymphocytes are derived from $\mathrm{CD} 2^{+}$precursors. $\mathrm{J}$. Immunol. 158:2134-2142.

30. Badley, A.D., J.A. McElhinny, P.J. Leibson, D.H. Lynch, M.R. Alderson, and C.V. Paya. 1996. Upregulation of Fas ligand expression by human immunodeficiency virus in human macrophages mediates apoptosis of uninfected T lymphocytes. J. Virol. 70:199-206.

31. Zhou, L.-J., and T.F. Tedder. 1996. CD14+ blood monocytes can differentiate into functionally mature $\mathrm{CD}^{+} 3^{+}$dendritic cells. Proc. Natl. Acad. Sci. USA. 93:2588-2592.

32. Dulbecco, R. 1988. Endpoint method-measurement of the infectious titer of a viral sample. In Virology: The Nature of Viruses, 2nd ed. J.P. Lippincott, Philadelphia. 22-25.

33. Kayagaki, N., A. Kawasaki, T. Ebata, H. Ohmoto, S. Ikeda, S. Inoue, K. Yoshino, K. Okumura, and. H. Yagita. 1995. Metalloproteinase-mediated release of human Fas ligand. J. Exp. Med. 182:1777-1783.

34. Takahashi, T., M. Tanaka, J. Inazawa, T. Abe, T. Suda, and H. Nagata. 1994. Human Fas ligand: gene structure, chormosomal location and species specificity. Int. Immunol. 6:1567-1574.

35. Panoskaltsis-Mortari, A., and R.P. Bucy. 1995. In situ hybridization with digoxigenin labeled RNA probes: facts and artifacts. Biotechniques. 18:300-307.

36. Falini, B., L. Flenghi, S. Pileri, M. Gambacorta, B. Bigerna, H. Durkop, F. Eitelbach, J. Thiele, R. Pacini, A Cavaliere, et al. 1993. PG-M1: a new monoclonal antibody directed against a fixative-resistant epitope on the macrophagerestricted form of the CD68 molecule. Am. J. Pathol. 142:1359-1372.

37. Kahn, H.J., A. Marks, H. Thom, and R. Baumal. 1983. Role of antibody to S100 protein in diagnostic pathology. Am. Soc. Clin. Pathol. 79:341-347.

38. Nakajima, M., A. Nakajima, N. Kayagaki, M. Honda, H. Yagita, and K Okumura. 1997. Expression of Fas ligand and its receptor in cutaneous lupus: implication in tissue injury. Clin. Immunol. Immunopathol. 83:223-229.

39. Kaplan, G., and G. Gaudernack. 1982. In vitro differentiation of human monocytes. J. Exp. Med. 156:1101-1114.

40. O'Doherty, U., R.M. Steinman, M. Peng, P.U. Cameron, S. Gezelter, I. Kopeloff, W.J. Swiggard, M. Pope, and N. Bhardwaj. 1993. Dendritic cells freshly isolated from human blood express CD4 and mature into typical immunostimulatory dendritic cells after culture in monocyte conditioned medium. $J$. Exp. Med. 178:1067-1078.

41. Dhawan, S., L.A. Toro, B.E. Jones, and M.S. Meltzer. 1992. Interactions between HIV infected monocytes and the extracellular matrix: HIV-infected monocytes secrete neutral metalloproteases that degrade basement membrane protein matrices. J. Leukocyte Biol. 52:244-248.

42. Tanaka, M., T. Suda, K. Haze, N. Nakamura, K. Sato, F. Kimura, K. Motoyoshi, M. Mizuki, S. Tagawa, S. Ohga, et al. 1996. Fas ligand in human serum. Nat. Med. 2:312-322.

43. Sarsfield, P., D.B. Jones, and D.H. Wright. 1996. Accessory cells in Crohn's disease of the terminal ileum. Histopathology (Oxf.). 28:213-219.

44. Tsang, W.Y.W., J.K.C. Chan, and C.S. Ng. 1994. Kikuchi's Lymphadenitis-A morphologic analysis of 75 cases with special reference to unusual features. Am. J. Surg. Pathol. 18:219-231.

45. Armitage, R.J. 1994. Tumor necrosis factor receptor superfamily members and their ligands. Curr. Opin. Immunol. 6:407-413.

46. Sytwu, H.-K., R.S. Liblau, and H.O. McDevitt. 1996. The roles of Fas/ APO-1 (CD95) and TNF in antigen-induced programmed cell death in T cell receptor transgenic mice. Immunity. 5:17-30.

47. French, L.E., A. Wilson, M. Hahne, I. Viard, J. Tschopp, and H. Robson MacDonald. 1997. Fas ligand expression is restricted to nonlymphoid thymic 
components in situ. J. Immunol. 159:2196-2202.

48. Süss, G., and K. Shortman. 1996. A subclass of dendritic cells kills CD4 T cells via Fas/Fas-ligand-induced apoptosis. J. Exp. Med. 183:1789-1796.

49. Maraskovsky, E., K. Brasel, M. Teepe, E.R. Roux, S.D. Lyman, K. Shortman, and H.J. McKenna. 1996. Dramatic increase in the numbers of functionally mature dendritic cells in Flt3 ligand-treated mice: multiple dendritic cell subpopulations identified. J. Exp. Med. 184:1953-1962.

50. Oyaizu, N., N. Kayagaki, H. Yagita, S. Pahwa, and Y. Ikawa. 1997. Requirement of cell-cell contact in the induction of Jurkat $\mathrm{T}$ cell apoptosis: the membrane-anchored but not soluble form of FasL can trigger anti-CD3-induced apoptosis in Jurkat T cells. Biochem. Biophys. Res. Commun. 238:670-675.

51. Oyaizu, N., Y. Adachi, F. Hashimoto, T.W. McCloskey, N. Hosaka, N. Kayagaki, N. Yagita, and S. Pahwa. 1997. Monocytes express Fas ligand upon CD4 cross-linking and induce $\mathrm{CD} 4^{+} \mathrm{T}$ cells apoptosis: a possible mechanism of bystander cell death in HIV infection. J. Immunol. 158:2456-2463.

52. Holtz-Heppelmann, C.J., A. Algeciras, A.D. Badley, and C.V. Paya.
1998. Transcriptional regulation of the human FasL promoter-enhancer region. J. Biol. Chem. 273:4416-4423.

53. Westendorp, M.O., R. Frank, C. Ochsenbauer, K. Stricker, J. Dhein, H. Walczak, K.-M. Debatin, and P.H. Krammer. 1995. Sensitization of T cells to CD95-mediated apoptosis by HIV-1 Tat and gp120. Nature. 375:497-500.

54. Chun, T.-W., L. Carruth, D. Finzi, X. Shen, J.A. DiGiuseppe, H. Taylor, M. Hermankova, K. Chadwick, J. Margolick, T.C. Quinn, et al. 1997. Quantification of latent tissue reservoirs and total body viral load in HIV-1 infection. Nature. 387:183-188.

55. Perelson, A.S., A.U. Neumann, M. Markowitz, J.M. Leonard, and D.D. Ho. 1996. HIV-1 dynamics in vivo: virion clearance rate, infected cell life-span, and viral generation time. Science. 271:1582-1586.

56. Muro-Cacho, C.A., G. Pantaleo, and A.S. Fauci. Analysis of apoptosis in lymph nodes of HIV-infected persons. Intensity of apoptosis correlates with the general state of activation of the lymphoid tissue and not with stage of disease or viral burden. J. Immunol. 154:5555-5566. 